\title{
ROLE OF PERCUTANEOUS NEEDLE BIOPSY OF AXILLARY LYMPH NODES TO EVALUATE NODE POSITIVE BREAST CANCER AFTER NEOADJUVANT CHEMOTHERAPY
}

\author{
Baiba Lìcīte ${ }^{1,2, \#}$, Arvīds Irmejs ${ }^{1,2,5}$, Jeḷena Maksimenko ${ }^{1,2,5}$, Pēteris Loža ${ }^{1,2}$, \\ Genādijs Trofimovičs ${ }^{1,2}$, Edvīns Miklaš̌evičs ${ }^{1,2,5}$, Jurijs Nazarovs ${ }^{4}$, Māra Romanovska ${ }^{4}$, \\ Justīne Deičmane ${ }^{6}$, Gunta Purkalne ${ }^{1,3}$, and Jānis Gardovskis 1,2,5'

\footnotetext{
${ }^{1}$ Department of Surgery, Rīga Stradiṇš University, 13 Pilsoṇu Str., Rīga, LV-1002, LATVIA

2 Department of Surgery, Pauls Stradiṇš Clinical University Hospital, 13 Pilsoṇu Str., Rīga, LV-1002, LATVIA

${ }^{3}$ Department of Oncology, Pauls Stradinš̌ Clinical University Hospital, 13 Pilsoṇu Str., Rīga, LV-1002, LATVIA

${ }^{4}$ Department of Pathology, Pauls Stradiṇš Clinical University Hospital, 13 Pilsoṇu Str., Rīga, LV-1002, LATVIA

${ }^{5}$ Institute of Oncology, Rīga Stradiṇš University, 13 Pilsoṇu Str., Rīga, LV-1002, LATVIA

${ }^{6}$ Department of Radiology, Pauls Stradiṇš Clinical University Hospital, 13 Pilsoṇu Str., Rīga, LV-1002, LATVIA

\# Corresponding author, baiba.licite@gmail.com
}

Contributed by Jānis Gardovskis

\begin{abstract}
The aim of the study was to evaluate the role of ultrasound guided fine needle aspiration cytology (FNAC) in the restaging of node positive breast cancer after neoadjuvant chemotherapy (NAC). From January 2016 - October 2018, 90 node positive stage IIA-IIIC breast cancer cases undergoing NAC were included in the study. The largest, most superficial and the most caudal axillary node metastasis confirmed by fine needle aspiration cytology (FNAC) was marked with clip. After $N A C$, restaging of axilla was performed with ultrasound and FNAC of the marked and/or the most suspicious axillary node. Of the 90 cases, 58 with available ultrasound guided percutaneous needle biopsy data were further evaluated. Axilla conserving surgery was performed in 37 of 58 cases and axillary lymph node dissection (ALND) in 21 of 58 cases. False Positive Rate (FPR) of FNAC after NAC was $12 \%$, False Negative Rate (FNR) - 58\%, sensitivity - 54\%, specificity $82 \%$, accuracy $62 \%$. FNAC after NAC had low FPR and was found to be useful in predicting residual axillary disease and to streamline surgical decision making regarding ALND. However, FNR was unacceptably high and FNAC alone was not able to predict ypCR and omission of further axillary surgery.
\end{abstract}

Key words: breast cancer, neoadjuvant, axilla, cytology.

\section{INTRODUCTION}

According to recent studies, pathological complete response (pCR) after neoadjuvant chemotherapy (NAC) in node positive breast cancer is observed in up to $40-75 \%$ of cases (Dominici et al., 2010; Boughey et al., 2014; Diego et al., 2016; Koolen et al., 2017). This means that the preoperative systemic therapy has completely eliminated all regional cancer involvement and total removal of all axillary lymph nodes is not indicated. However, until recently, axillary lymph node dissection (ALND) was performed in all node positive cases irrespective of response to NAC. According to a retrospective study performed in Pauls Stradinš Clinical University Hospital, total removal of unaffected axillary lymph nodes after NAC was performed in $31.6 \%$ of cases before 2016 (Puzāka and Irmejs, 2016). Restaging of axilla after NAC for node positive breast cancer is recommended according to the latest NCCN guidelines for breast cancer. However, the ways to achieve optimal axillary management after NAC are still not known (NCCN Breast Cancer Clinical Guidelines, Version 1.2018) (Vugts et al., 2016). Several preoperative and intraoperative axillary reevaluation approaches have been studied recently, including physical examination, imaging (e.g. ultrasound, PET-CT) and biopsy 
techniques (Boughey et al., 2015; Caudle et al., 2016). Studies on PET/CT imaging for axillary staging after NAC are controversial (Koolen et al., 2014). The combined clipped and sentinel node biopsy approach has a very low false negative rate $1.4 \%$, but a disadvantage is the necessity of intraoperative frozen section and/or potential for repeated axillary surgery in $\mathrm{cN} 2$ and $\mathrm{cN} 3$ cases (Caudle et al., 2016).

FNAC or core needle biopsy has been widely used to evaluate axillary nodal status in cases of breast cancer, but to the best of our knowledge there have been no reports on axillary lymphnode FNAC accuracy after NAC. The aim of the study was to evaluate the role of FNAC in the restaging of node positive breast cancer after NAC.

\section{MATERIALS AND METHODS}

The prospective cohort study was carried out at the state tertiary healthcare institution. The study was approved by the decision of Pauls Stradiňš Clinical University Hospital Medical Committee for Research Ethics. Patients signed a written informed consent.

From January 2016 to October 2018, 90 node positive stage IIA-IIIC breast cancer cases undergoing NAC were included in the study. Of these, $25(28 \%)$ of cases were HER2 positive, 16 (18\%) triple negative (TN) and 49 (54\%) Luminal. Cases were considered as TN if HER2 was negative and estrogen/progesteron was $<10 \%$. Of the 90 cases, 84 (93\%) had ductal, $5(6 \%)$ cases - lobular and $1(1 \%)$ medullary pathologies. Thirteen $(14 \%)$ cases were BRCA1 positive.

The largest, most superficial and the most caudal axillary node metastasis confirmed by fine needle aspiration cytology (FNAC) was marked with a V-mark ${ }^{\mathrm{TM}}$ Breast Biopsy Site Marker with Titanium Anchor (Argon Medical Devices, Inc), which was not visible in ultrasound in a considerable proportion of cases. Anchor localisation in the axillary lymphnode was confirmed by CT scan when necessary. The $\mathrm{cN}$ stage was diagnosed on the basis of pretreatment imaging (ultrasound and CT) data, the cN1 stage was considered if 1-3 involved axillary nodes were identified, the cN2 stage when more than three metastatic lymphnodes were visualised in axilla, and the $\mathrm{cN} 3$ stage was diagnosed if infra/supraclavicular lymphnode metastasis or more than ten affected axillary nodes were detected. cN1, cN2 and cN3 stages were observed in 56 (62\%), 15 (17\%) and 19 $(21 \%)$ cases, respectively.

After NAC, restaging of axilla was performed with ultrasound and FNAC of the marked and/or the most suspicious axillary node. During the last months of the study, lymph node biopsy was performed with alternate core needle biopsy method if technically possible. A modified algorithm of Netherlands cancer institute/Antoni van Levenhoek hospital (NCI/AVL) was followed to decide on axilla conserving surgery (ACS) versus ALND, as described by Koolen et al. (2017) ( Fig. 1). Modifications in our study included no use of PET-CT for clinical axillary staging and the clipped node was removed together with sentinel nodes during ACS to reduce false negative results of lymphnode pathology as much as possible.

In order to assess the diagnostic value of ultrasound guided FNAC, the false negative and false positive rate as well as sensitivity, specificity, positive predictive value (PPV), negative predictive value (NPV) and accuracy were calculated. Statistical analyses were performed using Medcalc, easy-to-use software and MS Excel 2010.

\section{RESULTS}

Of the 90 node positive stage IIA-IIIC breast cancer cases, $32(36 \%)$ pCR cases in axilla were observed, among which $12(38 \%)$ were HER2 positive, 11 (34\%) Luminal and 9 (28\%) were TN. There were considerably less Luminal cancers in the pCR group in comparison to full study group and this difference almost reached statistical significance $34 \%$ vs $54 \%(p=0.0529)$. Downstaging and upstaging of axillary nodal status after NAC took place in $56(62 \%)$ and $5(6 \%)$ cases, respectively. Axillary lymphnode percutaneous needle biopsy (FNAC or CNB) data after NAC were available in 55 of $90(61 \%)$ cases: $49(89 \%)$ - FNAC and $6(11 \%)$ - CNB. In another three $(3 \%)$ cases, FNAC after NAC was proposed, but not performed because all axillary lymphnodes had a normal structure in ultrasound and none were greater than $5 \mathrm{~mm}$, which would have made FNA technically challenging and questionable. Those cases also were included in further evaluation and were considered as

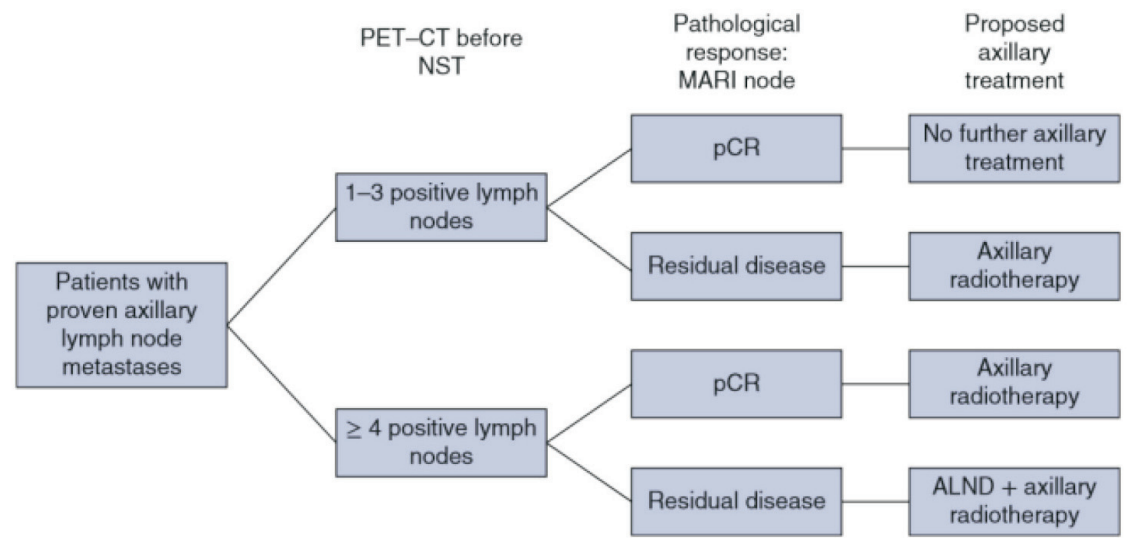

Fig. 1. Proposed axillary treatment after combining PET-CT before neoadjuvant systemic therapy (NST) and marking the axilla with radioactive iodine seeds (MARI procedure) after NST. 
Table 1

PATIENT GROUP CHARACTERISTICS BY CANCER SUBTYPE AND PCR, WHO HAD AVAILABLE DATA ABOUT AXILLARY LYMPHNODE PERCUTANEOUS NEEDLE BIOPSY (FNAC OR CNB) AFTER NAC

\begin{tabular}{lcc}
\hline \multicolumn{1}{c|}{ Subtype } & $\mathrm{n}, \%$ & $\mathrm{pCR}, \%$ \\
\hline Luminal & $31(54 \%)$ & $3(10 \%)$ \\
HER2 positive & $17(29 \%)$ & $6(35 \%)$ \\
TN & $10(17 \%)$ & $6(60 \%)$
\end{tabular}

biopsy negative cases after NAC. Altogether 58 cases were included for evaluation, of which 31 (54\%) were Luminal, $17(29 \%)$ - HER2 positive and $10(17 \%)$ showed TN (Table 1). Further, in 25 (43\%) cases malignant cells persisted in axillary lymphnodes in FNAC, and in 33 (57\%) cases no malignancy was detected, including one uninformative specimen.

In the 58 cases, 37 axilla conserving surgeries (ACS) and 21 ALND were performed. The number of examined nodes in the ACS group was 1-9, average 5 and in the ALND group -8 to 30 , average 16 . The difference between the number of retrieved nodes in ACS and ALND was statistically significant $(p<0.0001)$.

In 22 of $25(88 \%)$ cases with positive FNCA after NAC, metastasis in axillary lymphnodes was revealed in the pathology examination of the surgery specimen. ypN1mic, ypN1, ypN2 and ypN3 stages were detected in 1, 11, 7 and 3 cases, respectively. The false positive rate (FPR) of FNAC after NAC was 3 of 25 (12\%) cases. In the subgroup of 33 cases with negative lymphnode FNAC after NAC, surgery specimen examination revealed ypN0, ypN1mi, ypN1, ypN2 and ypN3 stages in 14, 5, 11, 2 and 1 cases, respectively. The false negative rate (FNR) of FNCA after NAC was 19 of 33 (58\%). Sensitivity, specificity, positive and negative predictive value as well accuracy of the test are shown in Table 2.

In further analysis of FNR and FPR subgroups, 13 of 22 (59\%) cases had the Luminal subtype, 8/22 (36\%) were HER 2 positive, and TN occurred in $1(5 \%)$ case. The proportion of TN cases was considerably less in FNR and FPR subgroups -10 of $58(17.2 \%)$ vs 1 of $22(4.5 \%)$, which may suggest that in the TN breast cancer group, FNA could have lower FNR and FPR and higher accuracy. However, this difference was not statistically significant $(p=0.1442)$.

Table 2

FNAC SENSITIVITY, SPECIFICITY, POSITIVE AND NEGATIVE PREDICTIVE VALUE AND ACCURACY AFTER NAC

\begin{tabular}{lcc}
\hline \multicolumn{1}{c|}{ Statistic } & Value & 95\% CI \\
\hline Sensitivity & $53.66 \%$ & $37.42 \%$ to $69.34 \%$ \\
Specificity & $82.35 \%$ & $56.57 \%$ to $96.20 \%$ \\
Positive predictive value & $88.00 \%$ & $71.64 \%$ to $95.51 \%$ \\
Negative predictive value & $42.42 \%$ & $33.15 \%$ to $52.27 \%$ \\
Accuracy & $62.07 \%$ & $48.37 \%$ to $74.49 \%$
\end{tabular}

A larger sample size is required to confirm that FNR and FPR rates after NAC are less in the TN molecular subtype.

Interestingly, FNR and FPR was $0 \%$ in the small subset of BRCA1 positive cases (9 of 58,16\%), which suggests another potential group in which percutaneous needle biopsy techniques could be of important diagnostic value, but again, a larger sample size is needed to confirm this.

\section{DISCUSSION}

Axillary pCR after NAC is a frequent event in the case of breast cancer (Dominici et al., 2010; Boughey et al., 2014; Diego et al., 2016; Koolen et al., 2017). Similarly, in our cohort we report axillary pCR in $36 \%$ of NAC. Therefore, it is very important to perform appropriate restaging in node positive breast cancers after NAC to avoid unnecessary ALND. One has to take in to account that pertuzumab is not approved for NAC in our country and with dual HER2 blockade, the pCR rate is expected to be even higher.

ACS, including clipped node biopsy alone or in combination with SNB has very low FNR (Caudle et al., 2016; Koolen et al., 2017) and is very good approach to restage the axilla after NAC. However, in a large proportion of node positive cases, especially in $\mathrm{cN} 2$ and $\mathrm{cN} 3$ stage, still considerable residual nodal involvement remains, which requires ALND. One solution is a use of a frozen section biopsy, but this approach has several disadvantages: potentially prolonged surgery time and rather high FNR - 33\% (Akay et al., 2018). This means that a considerable proportion of cases potentially require repeated surgery to perform ALND, which is not ideal management neither from the patient nor hospital perspective. Therefore, it is important in particular cases to attempt axilla restaging preoperatively.

There are data on effectiveness of axillary ultrasound and FNAC to evaluate nodal status prior to breast cancer treatment, and use of the ultrasound method alone after NAC has been evaluated (Pesek et al., 2017; Vijayaraghavan, 2017). However, to the best of our knowledge there are no data available on accuracy of axillary lymphnode FNAC and/or core needle biopsy (CNB) after NAC.

In our study, the false negative rate of FNCA after NAC was $58 \%$ and sensitivity $-53.66 \%$. The false positive rate was $12 \%$ and specificity was $82.35 \%$, with accuracy $62 \%$. In previous studies on the diagnostic value of axillary FNAC prior to NAC, sensitivity, specificity and accuracy have been estimated to lie between $41-80 \%, 96-100 \%$ and 70-89\%, respectively, but methodological differences exist (Ciatto et al., 2007; Cools-Lartigue and Meterissian, 2012; Hieken et al., 2013; Gipponi et al., 2016; Vidya and Bickley, 2017; Nakamura et al., 2018; Zhang et al., 2018). We conclude that in our study sensitivity of FNAC was close to the lowest range reported, but specificity and accuracy were clearly lower. The accuracy of axillary FNAC after NAC was somewhat lower than prior to NAC. Low sensitivity of axillary FNAC together with high FNR in this setting pre- 
cludes the omission of axillary surgery in spite of negative cytology. However, low FPR and specificity of the test is high enough to streamline surgical care with ALND for node-positive patients with considerable residual cancer burden expected. This approach has a potential to avoid frozen section biopsy and repeated axillary surgery in particular cases.

There are also reports that sensitivity and specificity of axillary ultrasound alone after NAC are 55\% and $88 \%$, respectively, which is very close to the results of our research (You et al., 2015; Baumgartner et al., 2018; Le-Petross et $a l ., 2018)$. However, pathological confirmation of the $\mathrm{ycN}$ stage is very important in surgical decision making, especially taking in to account that ultrasound method is highly operator dependent.

Our results show a trend towards lower FPR and FNR in the TN breast cancer subgroup, but a larger sample size is needed to confirm this, and to determine the potential for omission of axillary surgery in this subgroup on the basis of percutaneous biopsy only.

One of the potential biases of the study was inclusion of a small number of core needle biopsy cases. In a later stage of our study, the responsible surgeon chose between FNAC or core needle biopsy. However, according to literature, there are no considerable diagnostic value differences between these choices, but we presume that $\mathrm{CNB}$ is associated with smaller percentage of uninformative samples and repeated procedures respectively (Rao et al., 2009). Another disadvantage of the study was the inclusion of three cases where percutaneous biopsy after NAC was proposed, but rejected because of completely unaffected axillary imaging and technical difficulties to perform needle biopsy on very small size lymph nodes.

Like other studies, we report significantly lower axillary pCR rate in Luminal subtype breast cancers (Boughey et al., 2014). Lobular breast cancers have extremely low rates of pCR after NAC. As there were only three lobular cancer cases in our cohort, the sample size was too small for analysis (Loibl et al., 2014) (Johnson et al., 2016).

\section{CONCLUSION}

FNAC after NAC had a low $12 \%$ false positive rate and can aid to predict residual axillary disease and assist in surgical decision making regarding ALND. However, the false negative rate was unacceptable high and FNAC alone could not be able to predict ypCR and omission of further axillary surgery. In many cases, ACS is still the most optimal method to restage the axilla after NAC.

\section{ACKNOWLEDGEMENTS}

This work was supported by State Research Programme "Biomedicine for the public health (BIOMEDICINE)" pro- ject 5 "Personalised cancer diagnostics and treatment effectiveness evaluation".

\section{REFERENCES}

Akay, C. L., Albarracin, C., Torstenson, T., Bassett, R., Mittendorf, E. A., Yi, M., Kuerer, H. M., Babiera, G. V., Bedrosian, I., Hunt, K. K., Hwang, R. F. (2018). Factors impacting the accuracy of intra-operative evaluation of sentinel lymph nodes in breast cancer. Breast J., 24 (1), 28-34.

Baumgartner, A., Tausch, C., Hosch, S., Papassotiropoulos, B., Varga, Z., Rageth, C., Baege, A. (2018). Ultrasound-based prediction of pathologic response to neoadjuvant chemotherapy in breast cancer patients. Breast, 39, 19-23.

Boughey, J. C., Ballman, K. V., Hunt, K. K., McCall, L. M., Mittendorf, E. A., Ahrendt, G. M., Wilke, L. G., Le-Petross, H. T. (2015). Axillary ultrasound after neoadjuvant chemotherapy and its impact on sentinel lymph node surgery: Results from the American College of Surgeons Oncology Group Z1071 Trial (Alliance). J. Clin. Oncol., 33 (30), 3386-3393.

Boughey, J. C., McCall, L. M., Ballman, K. V., Mittendorf, E. A., Ahrendt, G. M., Wilke, L. G., Taback B, Leitch AM, Flippo-Morton T, Hunt, K. K. (2014). Tumor biology correlates with rates of breastconserving surgery and pathologic complete response after neoadjuvant chemotherapy for breast cancer findings from the ACOSOG Z1071 (alliance) prospective multicenter clinical trial. Ann. Surg., 260, 608-616.

Caudle, A. S., Yang, W. T., Krishnamurthy, S., Mittendorf, E. A., Black, D. M., Gilcrease, M. Z. et al. (2016). Improved axillary evaluation following neoadjuvant therapy for patients with node-positive breast cancer using selective evaluation of clipped nodes: Implementation of targeted axillary dissection. J. Amer. Soc. Clin. Oncol., 34 (10), 1072-1078.

Ciatto, S., Brancato, B., Risso, G., Ambrogetti, D., Bulgaresi, P., Maddau, C., ... Houssami, N. (2007). Accuracy of fine needle aspiration cytology (FNAC) of axillary lymph nodes as a triage test in breast cancer staging. Breast Cancer Res. Treat., 103 (1), 85-91.

Cools-Lartigue, J., Meterissian, S. (2012). Accuracy of axillary ultrasound in the diagnosis of nodal metastasis in invasive breast cancer: A review. World J. Surg., 36 (1), 46-54.

Diego, E. J., McAuliffe, P. F., Soran, A., McGuire, K. P., Johnson, R. R., Bonaventura, M., Ahrendt, G. M. (2016). Axillary staging after neoadjuvant chemotherapy for breast cancer: A pilot study combining sentinel lymph node biopsy with radioactive seed localization of pre-treatment positive axillary lymph nodes. Ann. Surg. Oncol., 23 (5), 1549-1553.

Dominici, L. S., Negron Gonzalez, V. M., Buzdar, A. U., Lucci, A., Mittendorf, E. A., Le-Petross, H. T., Babiera, G. V., Meric-Bernstam, F., Hunt, K. K., Kuerer, H. M. (2010). Cytologically proven axillary lymph node metastases are eradicated in patients receiving preoperative chemotherapy with concurrent trastuzumab for HER2-positive breast cancer. Cancer, 116 (12), 2884-2889.

Gipponi, M., Fregatti, P., Garlaschi, A., Murelli, F., Margarino, C., Depaoli, F., Baccini, P., Gallo, M., Friedman, D. (2016). Axillary ultrasound and Fine-Needle Aspiration Cytology in the preoperative staging of axillary node metastasis in breast cancer patients. Breast, 30, 146-150.

Hieken, T. J., Trull, B. C., Boughey, J. C., Jones, K. N., Reynolds, C. A., Shah, S. S., Glazebrook, K. N. (2013). Preoperative axillary imaging with percutaneous lymph node biopsy is valuable in the contemporary management of patients with breast cancer. Surgery, 154 (4), 831-840.

Johnson, J., Barmparas, G., Chung, A., Giuliano, A., Amersi, F. (2016). Predictors of complete response to neoadjuvant chemotherapy in breast cancer. Ann. Surg. Oncol., 23 (3), 378-379.

Koolen, B. B., Donker, M., Straver, M. E., van der Noordaa, M. E. M., Rutgers, E. J. T., Valdés Olmos, R. A., Vrancken Peeters, M. J. T. F. D. (2017). Combined PET-CT and axillary lymph node marking with radioactive iodine seeds (MARI procedure) for tailored axillary treatment in node-positive breast cancer after neoadjuvant therapy. Brit. J. Surg., 104 (9), 1188-1196. 
Koolen, B. B., Pengel, K. E., Wesseling, J., Vogel, W. V., Vrancken Peeters, M. J. T. F. D., Vincent, A. D., Gilhuijs KG, Rodenhuis S, Rutgers EJ, Valdés Olmos, R. A. (2014). Sequential 18F-FDG PET/CT for early prediction of complete pathological response in breast and axilla during neoadjuvant chemotherapy. Eur. J. Nucl. Med. Mol. Imaging, 41 (1), 32-40.

Le-Petross, H. T., McCall, L. M., Hunt, K. K., Mittendorf, E. A., Ahrendt, G. M., Wilke, L. G., Ballman, K. V., Boughey, J. C. (2018). Axillary ultrasound identifies residual nodal disease after chemotherapy: Results from the American College of Surgeons Oncology Group Z1071 Trial (Alliance). Amer. J. Roentgeno., 210 (3), 669-676.

Loibl, S., Volz, C., Mau, C., Blohmer, J. U., Costa, S. D., Eidtmann, H., et al. (2014). Response and prognosis after neoadjuvant chemotherapy in 1,051 patients with infiltrating lobular breast carcinoma. Breast Cancer Res. Treatment, 144 (1), 153-162.

Nakamura, R., Yamamoto, N., Miyaki, T., Itami, M., Shina, N., Ohtsuka, M. (2018). Impact of sentinel lymph node biopsy by ultrasound-guided core needle biopsy for patients with suspicious node positive breast cancer. Breast Cancer, 25 (1), 86-93.

Pesek, S. E., King, H. M., Koelliker, S., Raker, C., Edmonson, D., Dizon, D. S., Gass, J. (2017). Axillary ultrasound fine needle aspiration biopsy: Is there a role in the post Z-0011 era? Amer. J. Clin. Oncol., 41 (7), 702-707.

Puzāka, B., Irmejs, A. (2016). Paduses operācijas apjoms krūts vē̌̌a slimniecēm pēc neoadjuvantas ķimijterapijas. Rīgas Stradiņa universitāte, 2016. gada Zinātniskā konference, Rīgā, 2016. Tēzes, 207. lpp. [RSU Scientific Conference. Abstract Book 2016]. Available from:
https://www.rsu.lv/sites/default/files/imce/Zinātnes departaments/2016/V sekcija/paduses_operacijas_apjoms_kruts_vezis.pdf (accessed 15.05.2019).

Rao, R., Lilley, L., Andrews, V., Radford, L., Ulissey, M. (2009). Axillary staging by percutaneous biopsy: Sensitivity of fine-needle aspiration versus core needle biopsy. Ann. Surg.Oncol., 16 (5), 1170-1175.

Vidya, R., Bickley, B. (2017). Pre-operative axillary staging: Should core biopsy be preferred to fine needle aspiration cytology? Ecancermedicalscience, 11, 724

Vijayaraghavan, G. R., Vedantham, S., Kataoka, M., DeBenedectis, C., Quinlan, R. M. (2017). The relevance of ultrasound imaging of suspicious axillary lymph nodes and fine-needle aspiration biopsy in the post-ACOSOG Z11 era in early breast cancer. Acad. Radiol., 24 (3), 308-315.

Vugts, G., Maaskant-Braat, A. J. G., de Roos, W. K., Voogd, A. C., Nieuwenhuijzen, G. A. P. (2016). Management of the axilla after neoadjuvant chemotherapy for clinically node positive breast cancer: A nationwide survey study in The Netherlands. Eur. J. Surg. Oncol., 42 (7), 956-964.

You, S., Kang, D. K., Jung, Y. S., An, Y.-S., Jeon, G. S., Kim, T. H. (2015). Evaluation of lymph node status after neoadjuvant chemotherapy in breast cancer patients: comparison of diagnostic performance of ultrasound, MRI and ${ }^{18}$ F-FDG PET/CT. Brit. J. Radiol., 88 (1052), 20150143.

Zhang, F., Zhang, J., Meng, Q.-X., Zhang, X. (2018). Ultrasound combined with fine needle aspiration cytology for the assessment of axillary lymph nodes in patients with early stage breast cancer. Medicine, 97 (7), e9855.

\section{PERKUTĀNAS ADATAS BIOPSIJAS METOŽU NOZĪME PADUSES LIMFMEZGLU METASTĀŽU IZVĒRTĒŠANAI KRŪTS VĒŽA PACIENTĒM PĒC NEOADJUVANTAS ĶĪMIJTERAPIJAS}

Pētījuma mērkis ir izvērtēt tievās adatas aspirācijas citoloǵijas nozīmi pēc neoadjuvantas kīmijterapijas krūts vēža pacientēm ar metastāzēm paduses limfmezglos. Pētījumā tika iekḷauti 90 krūts vēža IIA-IIIC stadijas gadījumi, kuros konstatētas metastāzes paduses limfmezglos un, kas saṇēma neoadjuvantu ķīmijterapiju. Lielākais, virspusējākais un visvairāk kaudāli novietotais paduses limfmezgls, kurā citoloğiski tika konstatētas metastāzes, tika marḳēts ar klipu. Pēc neoadjuvantas ḳimijterapijas atkārtoti tika veikta ultrasonogrāfiska paduses limfmezglu izvērtēšana un tievās adatas aspirācijas citolog̣ija marḳētajam limfmezglam un/vai visvairāk suspektajam paduses limfmezglam. 58/90 gadījumos bija pieejami perkutānās adatas biopsijas dati, un šî pacientu grupa tika pētīta detalizēti. $37 / 58$ gadījumos tika veikta padusi saudzējoša operācija, bet $21 / 58$ gadījumā — paduses limfadenektomija. Tievās adatas aspirācijas dati pēc neoadjuvantas kīmijterapijas tika salīdzināti ar paduses operācijas datiem. Tievās adatas aspirācijas viltus pozitīvā vērtība pēc neoadjuvantas ķīmijterapijas ir 12\%, viltus negatīvā vērtība $-58 \%$, jutīgums $-54 \%$, specifiskums $-82 \%$, precizitāte $-62 \%$. Tievās adatas aspirācijas citoloğijas gadījumā viltus pozitīvā vērtība ir zema un testu ir lietderīgi izmantot, lai prognozētu reziduālas metastāzes paduses limfmezglos un jau pirms operācijas izšķirtos par operācijas apjomu — paduses limfadenektomiju. Tomēr viltus negatīvā vērtība ir pārlieku augsta, un testu nevar izmantot, lai prognozētu pilnu patoloğisku remisiju paduses limfmezglos, kas potenciāli ḷautu izvairīties no radikālas paduses operācijas. 